\title{
Thyrotrophin estimation in diagnosis and treatment of childhood thyroid disorders
}

\author{
DOREEN JACKSON, MAGDA VANDERSCHUEREN-LODEWEYCKX, and \\ D. B. GRANT \\ From The Hospital for Sick Children and Institute of Child Health, London
}

Jackson, D., Vanderschueren-Lodeweyckx, M., and Grant, D. B. (1975). Archives of Disease in Childhood, 50, 522. Thyrotrophin estimation in diagnosis and treatment of childhood thyroid disorders. Serum thyrotrophin (TSH) was estimated by double-antibody radioimmunoassay in 200 children aged 2 months to 16 years with normal thyroid function. There was no apparent variation in TSH with age or sex and only 4 children had TSH levels greater than $5 \mu \mathrm{U} / \mathrm{ml}$.

High TSH values were obtained in 9 children with primary hypothyroidism, in 3 children with thyroiditis, and in one girl with a lingual thyroid. Moderately raised TSH was found in 3 girls with thyroiditis, 2 brothers with goitres due to enzyme defect, and a girl with an ectopic thyroid. In one girl with a defect of iodine organification and in 3 boys with thyroxine binding globulin deficiency the TSH levels were normal despite very low serum thyroxine values.

Serum TSH was also estimated in 20 children during treatment for primary hypothyroidism. 3 of these children showed slightly raised TSH levels despite apparently adequate replacement therapy with L-thyroxine. One girl showed a very high TSH level 3 weeks after treatment had been temporarily withdrawn.

It is generally recognized that estimation of serum thyroxine $\left(\mathrm{T}_{4}\right)$ or protein bound iodine does not provide a completely reliable index of thyroid function as the results are also dependent on the serum concentration of the carrier protein thyroxine binding globulin (TBG). While this can be overcome by using techniques which allow for variation in serum TBG concentration, radioimmunoassays for thyrotrophin (TSH) are becoming more widely available and already provide an alternative method for evaluating children with suspected hypothyroidism (Greenberg et al., 1970; Hayek, Maloof, and Crawford, 1973).

This paper describes serum $\mathrm{T}_{4}$ and $\mathrm{TSH}$ findings in children with thyroid disorders or suspected hypothyroidism. The results provide further evidence for the value of TSH estimation in the diagnosis of hypothyroidism during childhood.

\section{Subjects and methods}

Children with normal thyroid function. Serum samples were obtained from 50 boys and 50 girls

Received 12 December 1974.

^Present address: Academisch Ziekenhuis Sint-Rafael, Kindergeneeskunde, 3000 Leuven, Kapucijnenvoer 33, Belgium. aged 2 months to 15 years with delayed growth or developmental retardation. None was considered to have a thyroid or pituitary disorder by the clinician in charge of the case. Specimens from 100 healthy children aged 8-16 years were kindly provided by Joan $M$. Round.

\section{Patients with thyroid disorders.}

Primary hypothyroidism. 3 infants ( 3 to 9 months) and 6 children ( 3 to 15 years) who showed clinical signs of hypothyroidism without a palpable goitre were studied before treatment. A further 17-year-old girl who had been treated with thyroxine since infancy was investigated 3 and 5 weeks after treatment had been discontinued.

Thyroiditis. Samples were obtained from 7 girls (7-15 years) with goitres and positive serological tests for thyroiditis. One of these girls had alopecia with delayed growth and retarded bone age. The remainder were clinically euthyroid. Blood was also obtained from 3 further girls ( 5 to 12 years) with firm thyroid enlargement but no signs of hypothyroidism. Although thyroid antibodies were not detected in these patients, autoimmune thyroiditis was considered the likely diagnosis.

Ectopic thyroid. 2 girls with lingual thyroids (8 and 16 years) and a girl aged 11 years with a sub- 
lingual thyroid were studied. One of the patients with a lingual thyroid showed clinical features of hypothyroidism.

Goitre due to enzyme defect. Samples were obtained from 3 children with probable defects of thyroxine synthesis. These patients showed a markedly increased thyroid uptake of ${ }^{132} I$. Only one, who was clinically euthyroid, showed a significant discharge of ${ }^{132}$ I after perchlorate. The exact nature of the enzyme defect was not established in 2 brothers who had retarded growth and bone maturation.

TBG deficiency. 3 boys with TBG deficiency were studied. The findings in 2 brothers have been published elsewhere (Grant, Minchin Clarke, and Putman, 1974). In the third boy, TBG deficiency was associated with congenital cytomegalovirus infection.

Hypothyroid children during treatment with L-thyroxine. Samples were obtained from 20 hypothyroid children (9 months to 19 years) during treatment with L-thyroxine $(0.1-0.2 \mathrm{mg} / \mathrm{d})$. These patients all showed normal or enhanced growth rates and were clinically euthyroid.

\section{Methods}

T4 was measured by competitive protein binding (Ryness, 1972). The normal range for children over the age of 1 month is $5 \mu \mathrm{g} / 100 \mathrm{ml}-15 \mu \mathrm{g} / 100 \mathrm{ml}$.

Serum TSH was estimated by double-antibody radioimmunoassay based on the method of Hall, Amos, and Ormston (1971). Human TSH 63/38 (supplied by the Medical Research Council) was used as the standard. TSH (supplied by the National Pituitary Agency (HS2) ) was iodinated with ${ }^{125} I$ using chloramine T. Antiserum was raised in a guinea pig immunized with human TSH (DEAE II) (prepared by Dr. Ann Hartree). Addition of human luteinizing hormone, follicle stimulating hormone, and chorionic gonadotrophin to the assay did not reduce the binding of ${ }^{125} \mathrm{I}-\mathrm{TSH}$ by this antiserum.

Aliquots $(0.1 \mathrm{ml})$ of pooled serum from hyperthyroid patients was added to each assay standard. The lower limit of sensitivity of the assay was 0.5 $\mu \mathrm{U} / \mathrm{ml} \mathrm{TSH}$ and the interassay coefficient of variation for a control serum (mean value $15 \cdot 6 \mu \mathrm{U} / \mathrm{ml}$ ) was $14 \%$.

\section{Results}

Children with normal thyroid function. TSH results in 200 children with normal thyroid function are summarized in the Table. There was no obvious variation in TSH with age and the results for boys and girls were similar. More than half the children had TSH values of $1 \mu \mathrm{U} / \mathrm{ml}$ or less, and levels greater than $5 \mu \mathrm{U} / \mathrm{ml}$ were obtained in only 4 subjects. One, a severely retarded microcephalic girl had a TSH value of $12 \cdot 8 \mu \mathrm{U} / \mathrm{ml}$ and a $\mathrm{T}_{4}$ of $4 \cdot 8 \mu \mathrm{g} / 100 \mathrm{ml}$. 3 boys with pseudohypo-

\section{TABLE}

Mean serum TSH levels $(\mu \mathrm{U} / \mathrm{ml})$ in children of different ages with normal thyroid function

\begin{tabular}{c|c|c|c|c|c|c}
\hline \multicolumn{1}{c|}{ Age } & $\begin{array}{c}2 \mathrm{~m} \\
\text { to } 1 \mathrm{yr}\end{array}$ & $\begin{array}{c}1-3 \\
\mathrm{yr}\end{array}$ & $\begin{array}{c}3-6 \\
\mathrm{yr}\end{array}$ & $\begin{array}{c}6-9 \\
\mathrm{yr}\end{array}$ & $\begin{array}{c}9-12 \\
\mathrm{yr}\end{array}$ & $\begin{array}{c}12-16 \\
\mathrm{yr}\end{array}$ \\
\hline Boys & $\begin{array}{c}1 \cdot 2 \\
(6)\end{array}$ & $\begin{array}{c}2 \cdot 3 \\
(10)\end{array}$ & $\begin{array}{c}1 \cdot 3 \\
(8)\end{array}$ & $\begin{array}{c}1 \cdot 0 \\
(10)\end{array}$ & $\begin{array}{c}1 \cdot 8 \\
(20)\end{array}$ & $\begin{array}{c}1 \cdot 2 \\
(54)\end{array}$ \\
Girls & $\begin{array}{c}2 \cdot 0 \\
(10)\end{array}$ & $\begin{array}{c}1 \cdot 2 \\
(12)\end{array}$ & $\begin{array}{c}2 \cdot 1 \\
(8)\end{array}$ & $\begin{array}{c}1 \cdot 1 \\
(10)\end{array}$ & $\begin{array}{c}1 \cdot 9 \\
(12)\end{array}$ & $\begin{array}{c}1 \cdot 0 \\
(40)\end{array}$ \\
\hline
\end{tabular}

Note: Number of subjects in each group in parentheses.

parathyroidism, short stature, and malabsorption, respectively, had TSH levels of $11 \cdot 8,5 \cdot 6$, and $6 \cdot 2$ $\mu \mathrm{U} / \mathrm{ml}$ but normal $\mathrm{T}_{4}$ values.

Children with thyroid disorders. Serum TSH and $\mathrm{T}_{4}$ results in untreated patients with thyroid disorders are shown in Fig. 1.

Primary hypothyroidism. Serum TSH levels from 32 to $1120 \mu \mathrm{U} / \mathrm{ml}$ were found in the children with untreated primary hypothyroidism. All these patients had serum $T_{4}$ values of $3.5 \mu \mathrm{g} / 100 \mathrm{ml}$ or less. In general, the highest $\mathrm{TSH}$ levels were found in the children with the lowest $T_{4}$ values and within the group there was a significant negative

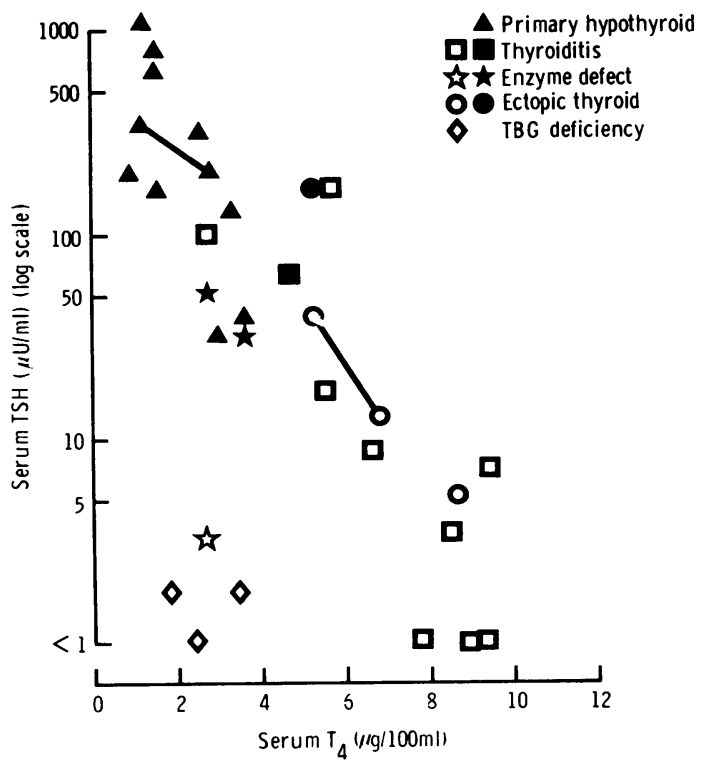

Fig. 1.-Serum TSH and $T_{4}$ values in 29 children with different thyroid disorders. Euthyroid subjects are indicated by open symbols. 
correlation between $\log \mathrm{TSH}$ and serum $\mathrm{T}_{4}$ $(\mathrm{r}=-0 \cdot 70 ; \mathrm{P}<0 \cdot 02)$.

Thyroiditis. In 3 girls with thyroiditis the TSH levels were very high $(62-170 \mu \mathrm{U} / \mathrm{ml})$ and the serum $\mathrm{T}_{4}$ values less than $5 \cdot 7 \mu \mathrm{g} / 100 \mathrm{ml}$. Only one of these patients showed definite evidence of hypothyroidism. In 3 further girls TSH ranged from $7 \cdot 7-18.5 \mu \mathrm{U} / \mathrm{ml}$ and $T_{4}$ from $5 \cdot 2-9 \cdot 3$ $\mu \mathrm{g} / 100 \mathrm{ml}$. TSH levels below $5 \mu \mathrm{U} / \mathrm{ml}$ were obtained in 4 patients.

Ectopic thyroid. The girl with a lingual thyroid and clinical hypothyroidism showed a high TSH level. Normal TSH and $\mathrm{T}_{4}$ results were obtained in the second patient with a lingual thyroid. Moderately raised TSH levels were found in the euthyroid child with a sublingual thyroid.

Enzyme defect. A girl with a partial iodinebinding defect had a low serum $\mathrm{T}_{4}$ but no rise in plasma TSH. Serum tri-iodothyronine $\left(\mathrm{T}_{3}\right)$ was slightly raised in this patient $(230 \mathrm{ng} / \mathrm{ml})$. Two mildly hypothyroid brothers with undetermined enzyme defects had raised TSH and low $\mathrm{T}_{4}$ values.

TBG deficiency. Results for 3 boys with TBG deficiency are also shown in Fig. 1. Serum $T_{4}$ levels of $3 \mu \mathrm{g} / 100 \mathrm{ml}$ or less were obtained, but serum TSH was not raised.

Patients on treatment with thyroxine. Serum $\mathrm{TSH}$ and $\mathrm{T}_{4}$ results in children receiving apparently adequate treatment with L-thyroxine are shown in Fig. 2. Two children with serum $T_{4}$ values of $7 \cdot 2-9 \cdot 3 \mu \mathrm{g} / 100 \mathrm{ml}$ showed moderately raised serum TSH $(21.6$ and $27.5 \mu \mathrm{U} / \mathrm{ml})$. $\mathrm{T}_{3}$ was estimated in one of these children and found

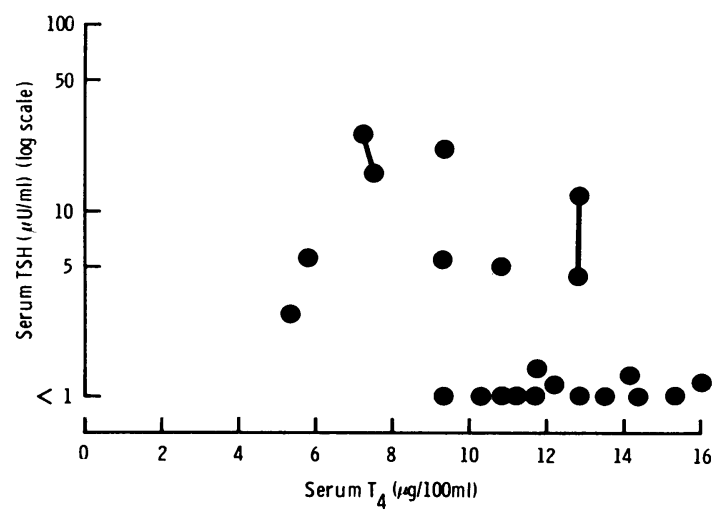

Fig. 2.-Serum $T S H$ and $T_{4}$ values in 20 children with primary hypothyroidism during treatment with L-thyroxine. to be normal $(120 \mathrm{ng} / 100 \mathrm{ml})$. In another child the TSH level was $11 \cdot 9 \mu \mathrm{U} / \mathrm{ml}\left(\mathrm{T}_{4} 12.9 \mu \mathrm{g} / 100 \mathrm{ml}\right)$, but a further sample gave a TSH value of $4 \cdot 3$ $\mu \mathrm{U} / \mathrm{ml}$. In the remaining children $\mathrm{TSH}$ values were less than $6 \mu \mathrm{U} / \mathrm{ml}$ and there was no significant relation between TSH and $\mathrm{T}_{4}$ for the group as a whole.

\section{Discussion}

TSH results obtained in children with normal thyroid function are somewhat lower than those reported by others (Chaussain, 1971; Lamberg et al., 1973; Golstein-Golaire and Delange, 1971). In the majority of patients the levels lay at the lower limit of sensitivity of the assay and only 4 children had values greater than $5 \mu \mathrm{U} / \mathrm{ml}$. It is of interest that one of these patients had pseudohypoparathyroidism, as Malvaux and Beckers (1973) have reported an exaggerated TSH response to thyrotrophin-releasing hormone in a patient with this disorder.

Golstein-Golaire and Delange (1971) found slightly raised TSH values in adolescent patients and Lamberg et al. (1973) reported that TSH levels in teenage girls are higher than those found in boys of the same age or in younger children. In the present study the results for boys and girls were similar and there was no evidence of a rise in serum TSH at the time of puberty. Chaussain (1971) was unable to show any change in serum TSH with age.

The high serum TSH values in patients with hypothyroidism are similar to those obtained by others in hypothyroid children (Hayek et al., 1973; Kulin et al., 1967; Barnes, Hayles, and Ryan, 1973). Both in previous reports and in the present series, very high values were found in some patients and it appears that the TSH levels in hypothyroid children may, in general, be higher than those found in adult patients (Mayberry et al., 1971; Hall et al., 1971). This apparent difference between adults and children may be related to changes in TSH secretion with age. Alternatively, it may merely reflect differences in the degree of thyroid insufficiency at the time of diagnosis. Our findings of an inverse relation between TSH and serum thyroxine in children with primary hypothyroidism appear to favour the latter explanation.

The results provide further evidence for the value of TSH estimation in assessment of primary hypothyroidism and it appears that a normal TSH result excludes this diagnosis. The value of the method is illustrated by the results in children with TBG deficiency, 2 of whom had previously been treated with L-thyroxine because of slow growth 
associated with a very low serum $T_{4}$. It should, however, be emphasized that patients with hypothyroidism secondary to pituitary or hypothalamic disorders will not have raised serum TSH levels, and in these cases estimation of TSH after giving thyrotrophin-releasing hormone may be necessary to confirm the diagnosis (Costom, Grumbach, and Kaplan, 1971).

It is already clear that a raised serum TSH level does not necessarily indicate the presence of hypothyroidism as there have been reports of high TSH values in adults and children with thyroiditis but no clinical or other laboratory evidence of hypothyroidism (Gordin et al., 1974; Greenberg et al., 1970). In the present small series of patients with thyroiditis, 2 girls without definite signs of hypothyroidism had very high TSH levels and in 3 further girls TSH was slightly raised. Similarly, a euthyroid girl with an ectopic thyroid showed modestly raised serum TSH and it appears that normal thyroid function was only maintained as a result of increased TSH secretion. There is still little information as to whether such patients are more likely to develop hypothyroidism than patients with normal serum TSH, but careful follow-up is indicated in such cases.

Raised TSH values have been previously described in patients with goitres due to enzyme defects (Harvey and Doniach, 1971) and 2 of the above patients with presumed biosynthetic abnormalities showed moderately raised TSH levels associated with clinical and laboratory evidence of hypothyroidism. However, one euthyroid child with a large goitre due to a partial defect in iodine binding had a normal TSH. Though this girl had a low serum thyroxine, her serum $\mathrm{T}_{3}$ was slightly raised, and it is of interest that Gomez-Pan, Evered, and Hall (1974) obtained similar $T_{3}$ and basal TSH results in 3 adults with Pendred's syndrome.

In some children who have been treated with thyroxine there may be doubt about the initial diagnosis of hypothyroidism and in such patients estimation of serum TSH after withdrawal of treatment may quickly clarify the situation. Hayek et al. (1973) found that TSH levels rose within 2 weeks of stopping treatment in a small group of children with hypothyroidism and one of the above patients showed very high TSH levels 3 weeks after treatment was temporarily withdrawn. It also appears that TSH assay may be useful in evaluating the correct dose of thyroxine in individual patients. The majority of the treated patients in the present study had low TSH levels. However, 3 patients who had consistently shown normal rates of growth and bone maturation had slightly raised
TSH values and it appears that adequate treatment may not always result in complete suppression of TSH secretion.

We thank Dr. Ann Hartree for human TSH used to raise antisera, Dr. R. L. Himsworth for assistance in obtaining serum from hyperthyroid patients, Professor R. Hall for advice on the radioimmunoassay for TSH, and Professor Barbara E. Clayton for encouragement and support. M.V-L was supported by grants from the British Council and from the Belgian 'National Fonds voor Wetenschappelijk Onderzoek'.

\section{REFBRENCES}

Barnes, N. D., Hayles, A. B., and Ryan, R. J. (1973). Sexual maturation in juvenile hypothyroidism. Mayo Clinic Proceedings, 48, 849.

Chaussain, J. L. (1971). Dosage de l'hormone thyréotrope sérique par la méthode radio-immunologique : son application à la détermination du taux sérique de l'enfant normal. Annales d'Endocrinologie, 32, 829.

Costom, B. H., Grumbach, M. M., and Kaplan, S. L. (1971). Effect of thyrotrophin-releasing factor on serum thyroidstimulating hormone. Fournal of Clinical Investigation, 50, 2219.

Golstein-Golaire, J., and Delange, F. (1971). Serum thyrotrophin level during growth in man. European fournal of Clinical Investigation, $1,405$.

Gomez-Pan, A., Evered, D. C., and Hall, R. (1974). Pituitary-thyroid function in Pendred's syndrome. British Medical fournal, 2, 152.

Gordin, A., Saarinen, P., Pelkonen, R., and Lamberg, B.-A. (1974). Serum thyrotrophin and the response to thyrotrophin-releasing hormone in symptomless autoimmune thyroiditis and in borderline and overt hypothyroidism. Acta Endocrinologica, $75,274$.

Grant, D. B., Minchin Clarke, H. G., and Putman, D. (1974) Familial thyroxine-binding globulin deficiency: search for linkage with $\mathrm{Xg}$ blood groups. Fournal of Medical Genetics, 11, 271.

Greenberg, A. H., Czernichow, P., Hung, W., Shelley, W., Winship, T., and Blizzard, R. M. (1970). Juvenile chronic lymphocytic thyroiditis: clinical, laboratory and histological correlations. Fournal of Clinical Endocrinology and Metabolism, 30, 293.

Hall, R., Amos, J., and Ormston, B. J., (1971). Radioimmunoassay of human serum thyrotrophin. British Medical fournal, 1,582 .

Harvey, R. F, and Doniach, D. (1971). Dyshormonogenetic goitre with high circulating levels of thyroid-stimulating hormone. Proceedings of the Royal Society of Medicine, 64, 299.

Hayek, A., Maloof, F., and Crawford, J. D. (1973). Thyrotrophin behaviour in thyroid disorders of childhood. Pediatric Research, 7, 28.

Kulin, H. E., Kohler, P. O., O'Malley, B. W., and Odell, W. D. (1967). Thyroid-stimulating hormone in thyroid dysgenesis. fournal of Pediatrics, 71, 714 .

Lamberg, B.-A., Kantero, R.-L., Saarinen, P., and Widholm, O. (1973). Endocrine changes before and after the menarche: IV. Serum thyrotrophin in female adolescents. Acta Endocrinologica, 74, 695.

Malvaux, P., and Beckers, C. (1973). Serum thyrotrophin response to thyrotrophin-releasing hormone in normal children and in patients with short stature and various endocrine or genetic diseases. Clinical Endocrinology, 2, 219.

Mayberry, W. E., Gharib, H., Bilstead, J. M., and Sizemore, G. W. (1971). Radioimmunoassay for human thyrotrophin: clinical value in patients with normal and abnormal thyroid function. Annals of Internal Medciine, 74, 471.

Ryness, J. (1972). The measurement of serum thyroxine in children. Fournal of Clinical Pathology, 25, 726.

Correspondence to Dr. D. B. Grant, The Hospital for Sick Children, Great Ormond Street, London WC1N 3JH. 